\title{
A TÖRÖK HÓDOLTSÁG KORI IDEGEN ETNIKUMOK ÖSSZEHASONLÍTÓ EMBERTANI VIZSGÁLATA
}

\author{
Kajdocsi Lovász Gabriella \\ Szegedi Tudományegyetem, Embertani Tanszék, Szeged \\ Témavezető: Dr. Molnár Erika
}

\begin{abstract}
Kajdocsi Lovász G.: Comparative anthropological analysis of non-Hungarian skeletal populations from the 16-17th centuries. It is well known from historical sources that in the Ottoman Era a large number of Southern Slavs and Vlachs settled down mainly in the southern parts of that-time Hungary. This study tried to answer the questions whether (1) it is possible to differentiate between these immigrant and resident populations based on metrical traits of skulls, and (2) it is possible to determine their origin. The other, larger research objective focused on the lifestyle of the examined populations: the investigation was supposed to determine differences and similarities in the lifestyles and health conditions of the two largest immigrant populations of Bácska (Bácsalmás-Óalmás and Zombor-Repülötér sites).

According to the results of distance calculation, almost all remains of the immigrant males from the time of the Turkish occupation in the territory of Hungary tendentiously belonged to one group and strongly differed from the Hungarian findings of the Árpád Age and the Late Middle Ages. The presumed common origin is thus verified with biological methods and on the basis of burial customs and grave goods as well. As for the origins of the examined populations, the foreign parallels clearly point out a connection to the territory of the Balkan, more specifically to the area populated by the Vlachs.

The results of the examination of pathological changes have pointed out the dissimilarity of health conditions and lifestyle among the immigrant populations. Moreover, the material from both the Bácsalmás and the Zombor cemeteries belong to the first series to have undergone examination of early-stage/atypical lesions of tuberculosis. On one hand, these results indicate a much higher prevalence of tuberculosis infection in that period, than it is shown by the frequency of classic lesions. On the other hand, they also demonstrate how much manifestations of the disease in individual series can differ.
\end{abstract}

Keywords: Carpathian Basin; Immigrants in the Late Middle Ages; Systematic cluster analysis; Paleopathology; Tuberculosis.

\section{Bevezetés}

Történeti forrásokból ismert, hogy a török hódoltság idején nagy tömegben telepedtek le délszlávok az akkori Magyarország területére, elsősorban a déli részekre. A hódoltság kori balkáni népesség hagyatékát azonban sokáig mellőzte, vagy nem ismerte fel a régészeti kutatás. Ennek köszönhetően a 16-17. század régészeti emlékei alig ismertek, bár majdnem minden múzeumban találhatók erre az időszakra datálható leletek. A hódoltság kori balkáni népesség korszerü régészetének megindítása az 1980-as évekig váratott magára, de igazi lendületet csupán a 2000-es évek elején vett, Wicker Erika vezetésével (Gaál 1982, Wicker 2008). Mindezek miatt a hódoltság kori idegen etnikumok átfogó antropológiai vizsgálatára is csak a közelmúltban kerülhetett sor. Ebben jelentős szerepet játszik a Szegedi Tudományegyetem Embertani Tanszékének 
2003 óta folytatott kutatása, melynek keretében már 7 embertani széria vizsgálatára került sor (Molnár és mtsai 2008). Jelen dolgozat, e kutatáshoz kapcsolódva, Bácska két legnagyobb török kori embertani szériáját mutatja be, illetve hasonlítja össze.

\section{Célkitüzések}

A 16-17. századi délszlávok kutatásának egyik legfontosabb kérdése az, hogy meghatározható-e a balkáni eredetű népesség pontos etnikuma. Ennek érdekében a következő kérdésekre kerestem a választ:

- A hódoltság idején betelepült idegen etnikumok a koponya metrikus jellegei alapján elkülöníthetőek-e a már itt élt népességektől - az Árpád-kori és a késő középkori, a régészeti leletek alapján magyar etnikumnak vélt temetők embertani anyagától?

- Mutatnak-e párhuzamot a balkáni területekröl származó adatokkal? Megállapítható-e az eredetük?

A kutatás másik nagyobb témaköre a vizsgált népességek életmódjára irányult. Ennek keretében a következő kérdésre kerestem a választ:

- Bácska két legnagyobb, régészeti szempontból azonos kultúrához tartozó népessége életmódjában, illetve egészségi állapotában hasonlít-e egymásra?

\section{Anyag és módszer}

A disszertáció vizsgálati anyagának kiválasztásánál szempont volt, hogy a temetők statisztikai szempontból megfelelő méretủek, illetve a régészeti leletanyaguk alapján egységesek legyenek. A kritériumoknak Bácsalmás-Óalmás és Zombor-Repülőtér leletegyüttesek feleltek meg.

A bácsalmás-óalmási homokbánya területén feltárt késő középkori temetőből 19932003 között, több szakaszban 481, többségében kiemelkedöen jó megtartású egyén csontvázmaradványa került elő (Wicker 2008). A szériában a subadultus-ok és a felnőttek aránya $51,5 \%: 48,6 \%$, a férfiak és a nők aránya - a meghatározható nemü fiatalkorú egyéneket is beleszámítva - pedig 52,7\%:47,3\%. A koponyaméretek tekintetében jellemző a rövid-középhosszú, széles, magas, hyperbrachykran-brachykran agykoponya és a közepesen széles, közepesen magas arckoponya. A termetük nagyközepes-magas.

A zombor-repülötéri temető leletmentő ásatására a második világháború idején került sor (Bartucz 1960, Korek 1994). A feltárás során 196 egyén többnyire közepes megtartású csontvázmaradványa került elő. A népességben a subadultus-ok és a felnőttek aránya $33,7 \%: 66,3 \%$, a férfiak és a nők aránya a meghatározható nemü fiatalkorú egyénekkel együtt pedig 47\%:53\%. A méretek alapján agykoponyájuk jellemzően közepesen hosszú, széles, magas-középmagas, hyperbrachykran-brachykran, az arckoponyájuk pedig széles-középszéles és közepesen magas. A termet mindkét nem esetében magas.

A vizsgált temetők eredetének tisztázásához elsősorban a szegedi Embertani Tanszéken feldolgozott idegen etnikumú temetők adatait használtam, amelyeket kiegészítettem a szakirodalomból ismert, szintén idegen etnikumú temetők adataival. Összehasonlító anyagként Árpád- és késő középkori magyarországi, valamint középkori délszláv és román temetöket használtam fel. A kapcsolatok feltérképezéséhez a szisztematikus klaszteranalízis módszerét alkalmaztam: a metrikus adatokból történő többféle biológiai távolságérték (euklidészi, maximum, Manhattan és Penrose) kiszámítása után egy hierarchikus és egy nem-hierarchikus klaszteranalízis (Ward-féle, 
K-közép) kombinációjával csoportokat képeztem. A tényleges kapcsolatok feltérképezésének érdekében azon csoportosulásokat tekintettem valósnak, melyek az elemzésekben tendenciaszerüen jelentkeztek (Fóthi és Fóthi 1990, 1992). Mivel a balkáni publikációk többségében csak a férfiak paramétereit közölték, az elemzést csak a férfiak adataival végeztem el.

A Bácsalmás-Óalmás, illetve a Zombor-Repülőtér leletegyüttesek biológiai rekonstrukciójának fontos eleme volt a csontozaton megfigyelhető patológiás csontelváltozások megfigyelése, amely segítségével a vizsgált népességek életkörülményei, egészségi állapota ismerhető meg és hasonlítható össze. A kóros elváltozásokat nozológiai szempontok alapján csoportosítva vizsgáltam, alapvetően makroszkópos morfológiai módszerekkel (pl. Steinbock 1976, Endes 1983, Aufderheide és Rodriguez-Martin 1998, Ortner, 2003). Több esetben azonban a diagnózis megerősítéséhez a következő kiegészítő módszerek alkalmazására került sor: radiológiai elemzések, paleohisztológiai vizsgálatok, molekuláris biológiai vizsgálatok (paleoproteomikai és paleomikrobiológiai analízis; Schultz 2001, Lovász és mtsai 2007, 2013, Boros-Major és mtsai 2011, Pálfi és mtsai 2012, Pósa és mtsai 2013, 2015). A különböző megbetegedések gyakoriságának összehasonlító elemzésénél $\chi^{2}$ próbát használtam, figyelembe véve a szériák különbözö megtartási állapotát.

\section{Vizsgálati eredmények}

A távolságszámítások eredményeit összegezve elmondható:

- A Magyarországon feltárt és a régészeti leletek alapján idegen eredetünek meghatározott (a hódoltság idején betelepült/betelepített) népességek férfiai a különböző távolságszámítási és klaszterezési módszerek alkalmazásával is tendenciaszerüen egy csoportba tartoznak.

- A hét, egymással szorosabb kapcsolatot mutató idegen eredetű sorozat a férfiak koponyaméretei alapján a magyarországi Árpád-kori, illetve a késő középkori leletegyüttesektől is markánsan elkülönül. Az idegen eredetü sorozatokkal szorosabb kapcsolatot mutató további öt magyarországi széria esetében néhánynál már a korábbi antropológiai vizsgálatok is rámutattak a lehetséges idegen kapcsolatokra.

- A vizsgált népességek eredetére vonatkozóan a külföldi párhuzamok egyértelmüen rámutattak a balkáni, ezen belül a vlahok által benépesített területekkel való kapcsolatokra.

A temetkezési szokások és a mellékletek alapján feltételezett közös, balkáni eredet így biológiai módszerekkel is megerősítést nyert. További, elsősorban a régészeti leletanyag alapján feltételezett szerbiai, macedóniai párhuzamok az összehasonlító anyag hiányában azonban egyelőre nem igazolhatók.

A vizsgált népességek életmódjának és egészségi állapotának felmérésére irányuló kutatás során a következő megállapításokra jutottam:

- Az egészségi állapot indikátorai, mint pl. a fertőzések és a poroticus hyperostosis gyakorisága azt mutatja, hogy a korábbi korszakokból származó magyarországi és balkáni szériákhoz képest mindkét temető népességének meglehetősen rossz volt az egészségi állapota. A nem-specifikus és specifikus fertőzések gyakoriságait a késő középkori magyarországi és balkáni adatokkal összehasonlítva viszont az is látható, hogy a bácsalmási népesség egészségi állapota a korszak adataihoz képest kifejezetten rossz volt (Lovász és mtsai 2005, 2007, 2012, Boros-Major és mtsai 2011, Neparáczki és mtsai 2011, Pálfi és mtsai 2012, Pósa és mtsai 2013, 2015), míg a zomboriaké átlagosnak 
tekinthető (Lovász 2010, Lovász és mtsai 2009, 2010). A két népesség közötti különbség föleg abban rejlik, hogy a bácsalmásiak között a subadultus-ok és a felnőttek körében is rendkívül magas a fertőzésre utaló elváltozások gyakorisága, míg a zomboriaknál a felnőttek kevésbé érintettek. Ezen adatok, valamint az egyéb táplálkozás- és aktivitás indikátorok aránya alapján a különbség oka az életkörülmények eltérése és/vagy a másmás kórokozókkal való fertőzöttség lehet. Utóbbit támasztja alá a tuberkulózis gyakoriságának és megjelenési formájának különbözősége is a két szériában.

- Az aktivitás-jelzők, úgy mint a traumák, illetve az ízületek elváltozásainak gyakorisága jelentős életmódbeli eltérést is sugall a két populáció között. A bácsalmási népesség tagjai fiatalon is kemény fizikai munkát végezhettek, amely a történeti források alapján állattenyésztés és földmüvelés lehetett (Lovász és mtsai 2005). A zomboriak körében jelentősen kevesebb az ízületi elváltozás, illetve az életkor és szexus szerinti gyakoriságok is különböznek a bácsalmási adatoktól - ez más jellegü munkavégzésre utal mind a férfiaknál, mind a nöknél. Emellett a zomboriak körében megfigyelt szignifikánsan nagyobb trauma-gyakoriság azt sugallja, hogy a népesség férfi tagjainak inkább harci jellegü feladataik voltak (Lovász és mtsai 2008, 2009). A zombori vár közelsége és katonai státusza is erősíti ezt a feltételezést (Hegyi 2007).

- Az életkörülménybeli eltérés nagy valószínűséggel nem érintette a táplálkozási szokásokat, ezek indikátorai (a poroticus hyperostosis, a skorbut, az osteoporosis, illetve a DISH gyakoriságai) hasonlóságot mutatnak a két népesség között. A vizsgált megbetegedések aránya megerősíti azt a feltételezést, amely szerint a régészeti leletanyag mennyisége és jellege alapján mindkét népességben többségében szegények éltek (Lovász és mtsai 2005, 2012, 2013).

- Emellett nincs különbség a D-vitamin hiány okozta léziók gyakoriságában sem. A viszonylag alacsony értékek azt jelzik, hogy valószínűleg elegendő napfény érte testüket - ez alapján ruházatuk laza volt, és ha át is vették a muszlim öltözködési szokásokat, akkor a nők fejviselete inkább a fényt jobban áteresztő fátyol lehetett, és az arcot valószínüleg nem fedték el vele (Wicker 2008).

- Szintén nem látható különbség a fejlödési rendellenességek gyakorisága tekintetében: a léziók nagy arányban érintik mindkét népesség tagjait, ami endogámiára utalhat. A különböző jellegek előfordulási mintázata azonban azt mutatja, hogy a két népesség között nem volt közvetlen genetikai kapcsolat.

\section{Eredmények értékelése}

A török hódoltság során betelepült idegen etnikumok kutatásában mérföldkőnek számít, hogy biológiai módszerekkel is sikerült igazolni a balkáni eredetet, illetve a késő középkori és Árpád-kori magyarországi szériáktól való különbözőséget. Szintén jelentős eredmény, hogy a patológiás elváltozások vizsgálatán keresztül sikerült rámutatni a betelepült népességek egészségi állapot- és életmódbeli heterogenitására is. Emellett mind a bácsalmási, mind a zombori temető leletanyaga azon szériák közé tartozik, amelyeknél elsőként történt meg a tbc korai stádiumú/atípusos elváltozásainak vizsgálata. Az eredmények egyrészt rámutattak, hogy a korszakban sokkal magasabb volt a tuberkulózis-fertőzöttség, mint amit a klasszikus léziók gyakorisága jelez; másrészt arra is rávilágítottak, hogy mennyire különbözött a kór megjelenési formája az egyes szériákban.

A török hódoltság korszakából származó idegen etnikumú temetők vizsgálata azonban számos további kutatási potenciállal is rendelkezik. Egyrészt az újonnan feltárt temetők 
vizsgálata hozzájárulhat a népességek egymás közötti kapcsolatainak feltérképezéséhez: az újonnan betelepülök az írott források szerint ugyanis gyakran költöztek a megszállt területeken belül, vagy magyar kézen maradt földre (pl. győri rácok; Wicker 2008). Amennyiben a balkáni területeken (elsősorban Szerbia, Macedónia és Montenegró) is publikálják középkori temetők kraniometriai adatait, lehetővé válik a magyarországi szériák eredetének pontosabb meghatározása, és a vizsgálatok kiterjeszthetőek lesznek a női adatok elemzésére is. A jelen dolgozatban ismertetett patológiás elváltozások további elemzése is több lehetőséget rejt. Ezek közül talán a legfontosabb az a már megkezdett projekt, melynek keretében a bácsalmási szériában megfigyelt korai stádiumú/atípusos tbc-s elváltozásokat elemezzük és egészítjük ki a molekuláris vizsgálatok eredményeivel. A molekuláris vizsgálatok kiterjesztése a korszakból származó többi temetőre, majd a szériák Mycobacterium tuberculosis aDNS pozitív eseteinek spoligotyping, illetve szekvenálási eredményei rámutathatnak a fertőző ágensek eredetére és a tuberkulózis különböző manifesztációinak hátterére is.

\section{Felhasznált irodalom}

Aufderheide, A.C., Rodríguez-Martín, C. (1998): The Cambridge encyclopedia of human paleopathology. Cambridge University Press, Cambridge.

Bartucz, L. (1960): Die anthropologischen Merkmale der Bevölkerung aus der Umgebung von Zombor (Sombor) im XV-XVII. Jahrhundert. Annales Universitatis Scientarium Budapestinensis de Rolando Eötvös Nominatae: Sectio Biologica, 3: 23-48.

Boros-Major, A., Bóna, A., Lovász, G., Molnár, E., Marcsik, A., Pálfi, Gy., Márk, L. (2011): New perspectives in biomolecular paleopathology of ancient tuberculosis: A proteomic approach. Journal of Archaeological Science, 38: 197-201. DOI: 10.1016/j.jas.2010.09.008

Endes, P. (1983): Pathologia. Medicina Könyvkiadó, Budapest.

Fóthi, E., Fóthi, Á. (1990): A cluster analysis model for grouping palaeoanthropological series. Annales Historico-Naturales Musei Nationalis Hungarici, 82: 235-240.

Fóthi, E., Fóthi, Á. (1992): Systematic cluster analysis for the grouping of anthropological series. Anthropologie, 30: 1-4.

Gaál, A. (1982): A dombóvár-békatói 16-17. századi temető. A Béri Balogh Ádám Múzeum Évkönyve, 10-11: 133-224.

Hegyi, K. (2007): A török hódoltság várai és várkatonasága. II. kötet. História. MTA Történettudományi Intézete, Budapest.

Korek, J. (1994): A Zombor-bükkszállási 17. századi temető sírleletei. A Móra Ferenc Múzeum Évkönyvei: Studia Archaeologica, 1989/1990: 181-202.

Lovász, G. (2010): Tuberkulózis a Zombor-repülőtéri késő középkori temető embertani anyagában. Museion, 9: 159-171.

Lovász, G., Marcsik, A., Pálfi, Gy., Molnár, E. (2009): Paleopathology of the late medieval graveyard of Zombor-Repülőtér. In: Pálfi, Gy., Molnár, E., Bereczki, Zs., Pap, I. (Eds) Des Lésions du Passé aux Diagnostics Modernes. University Press, Szeged. 72-73.

Lovász, G., Molnár, E., Gödde, J., Schultz, M., Marcsik, A. (2007): Skeletal manifestations of scurvy in a medieval anthropological series from Hungary. In: Wittwer Backofen, U. (Ed.) 7. Kongress der Gesellshaft für Anthropologie e. V.: „Anthropologie - Eine Wissenshaft in der Öffentlichkeit", Abstracts. Freiburg.

Lovász, G., Molnár, E., Marcsik, A. (2005): Bácsalmás-Óalmás 16-17. századi temető paleopatológiai vizsgálatának eredményei (2001-2003-as feltárás). In: Korsós, Z. (Szerk.) IV. Kárpát-medencei Biológiai Szimpózium, Elöadások összefoglalói. Budapest, 153-158.

Lovász, G., Molnár, E., Marcsik, A., Pálfi, Gy. (2008): Palaeopathology of a late medieval series from Serbia. In: 17th European Meeting of the Paleopathology Association, Programme and Abstracts. Copenhagen. pp. 59. 
Lovász, G., Molnár, E., Pálfi, Gy., Pósa, A., Wicker, E. (2012): "Sátorlakó vándorok" a török kori Észak Bácskában. Bácsország, 2012/1: 68-73.

Lovász, G., Pálfi, Gy., Marcsik, A., Pósa, A., Neparáczki, E., Molnár, E. (2010): Skeletal Manifestation of Tuberculosis in a Late Medieval Anthropological Series from Serbia. Acta Biologica Szegediensis, 54: 83-91.

Lovász, G., Schultz, M., Gödde, J., Bereczki, Zs., Pálfi, Gy., Marcsik, A., Molnár, E. (2013): Skeletal manifestations of infantile scurvy in a late medieval anthropological series from Hungary. Anthropological Science, 121: 173-185. DOI: 10.1537/ase.130905

Molnár, E., Marcsik, A., Hegyi, A., Paja, L., Wicker, E. (2008): Török hódoltság kori idegen etnikumok összehasonlító embertani elemzése. OTKA Munkabeszámoló.

Neparáczki, E., Török, T., Pósa, A., Molnár, E., Lovász, G., Maixner, F., Zink, A., Dutour, O., Pálfi, Gy. (2011): Preliminary results from the paleomicrobiological studies of Mycobacterium tuberculosis infection in the Bácsalmás-Óalmás anthropological series. Acta Biologica Szegediensis, 55: 41-45.

Ortner, D.J. (2003): Identification of pathological conditions in human skeletal remains. Academic Press, San Diego.

Pálfi, Gy., Zink, A., Maixner, F., Pósa, A., Lovász, G., Wicker, E., Bereczki, Zs., Molnár, E. (2012): Egy késő-középkori embertani széria tuberkulózis fertőzöttségének vizsgálata morfológiai és molekuláris biológiai módszerekkel. Anthropologiai Közlemények, 53: 37-52.

Pósa, A., Maixner, F., Lovász, G., Molnár, E., Bereczki, Zs., Zink, A., Pálfi, Gy. (2013): Revision of tuberculous lesions in the Bácsalmás-Óalmás series - preliminary morphological and biomolecular studies. Anthropologischer Anzeiger, 70: 83-100. DOI: 10.1127/0003$5548 / 2012 / 0260$

Pósa, A., Maixner, F., Sola, Ch., Bereczki, Zs., Molnár, E., Masson, M., Lovász, G., Spekker, O., Wicker, E., Perrin, P., Dutour, O., Zink, A., Pálfi, Gy. (2015): Tuberculosis infection in a latemedieval Hungarian population. Tuberculosis, 95: S60-S64. DOI: 10.1016/j.tube.2015.02.010

Schultz, M. (2001): Paleohistology of bone: A new approach to study of ancient diseases. Yearbook of Physical Anthropology, 44: 106-147. DOI: 10.1002/ajpa.10024

Steinbock, R.T. (1976): Paleopathological Diagnosis and Interpretation. Charles C. Thomas Publisher, Springfield.

Wicker, E. (2008): Rácok és vlahok a hódoltság kori Észak-Bácskában. Bács-Kiskun Megyei Önkormányzat Múzeumi Szervezete, Kecskemét.

\section{A doktori értekezéshez kapcsolódó, referált, impakt faktorral rendelkezó folyóiratokban megjelent tanulmányok}

Lovász, G., Schultz, M., Gödde, J., Bereczki, Zs., Pálfi, Gy., Marcsik, A., Molnár, E. (2013): Skeletal manifestations of infantile scurvy in a late medieval anthropological series from Hungary. Anthropological Science, 121(3): 173-185. DOI: 10.1537/ase.130905

Pósa, A., Maixner, F., Sola, Ch., Bereczki, Zs., Molnár, E., Masson, M., Lovász, G., Spekker, O., Wicker, E., Perrin, P., Dutour, O., Zink, A., Pálfi, Gy. (2015): Tuberculosis infection in a latemedieval Hungarian population. Tuberculosis, 95: S60-S64. DOI: 10.1016/j.tube.2015.02.010

\section{A doktori értekezéshez kapcsolódó további publikációk}

Boros-Major, A., Bóna, A., Lovász, G., Molnár, E., Marcsik, A., Pálfi, Gy., Márk, L. (2011): New perspectives in biomolecular paleopathology of ancient tuberculosis: A proteomic approach. Journal of Archaeological Science, 38(1): 197-201. DOI: 10.1016/j.jas.2010.09.008

Lovász, G. (2008-2009): Antropološka obrada srednjovekovne nekropole iz Sombora. Godišnjak Gradskog muzeja u Somboru, 2-3: 141-168.

Lovász, G. (2009): A zombor-repülőtéri temető általános antropológiai vizsgálata. Museion, 8: 143-157. 
Lovász, G. (2010): Tuberkulózis a Zombor-repülőtéri késő középkori temető embertani anyagában. Museion, 9: 159-171.

Lovász, G. (2011): Délszlávok a hódoltság kori Magyarországon - biológiai távolságszámítás a hódoltság kori Magyarországra települt idegen etnikumok körében. Museion, 10: 125-139.

Lovász, G., Molnár, E., Marcsik A. (2005): Bácsalmás-Óalmás 16-17. századi temető paleopatológiai vizsgálatának eredményei (2001-2003-as feltárás). In: Korsós, Z. (Szerk.) Elöadáskötet. IV. Kárpát-medencei Biológiai Szimpózium. Budapest, 153-158.

Lovász, G., Molnár, E., Marcsik, A. (2007): Tuberkulózisra utaló elváltozások megjelenése két késő középkori temető embertani anyagában. In: Korsós, Z., Gyenis, Gy., Penszka, K. (Szerk.) Elöadáskötet. V. Kárpát-medencei Biológiai Szimpózium. Budapest, 165-174.

Lovász, G., Molnár, E., Pálfi, Gy., Pósa, A., Wicker, E. (2012): „Sátorlakó vándorok” a török kori Észak Bácskában. Bácsország - Vajdasági Honismereti Szemle, 2012/1: 68-73.

Lovász, G., Pálfi, Gy., Marcsik, A., Pósa, A., Neparáczky E., Molnár E. (2010): Skeletal Manifestation of Tuberculosis in a Late Medieval Anthropological Series from Serbia. Acta Biologica Szegediensis, 54(2): 83-91.

Neparáczki, E., Török, T., Pósa, A., Molnár, E., Lovász, G., Maixner, F., Zink, A., Dutour, O., Pálfi, Gy. (2011): Preliminary results from the paleomicrobiological studies of Mycobacterium tuberculosis infection in the Bácsalmás-Óalmás anthropological series. Acta Biologica Szegediensis, 55(1): 41-45.

Pálfi, Gy., Zink, A., Maixner, F., Pósa, A., Lovász, G., Wicker, E., Bereczki, Zs., Molnár, E. (2012): Egy késő-középkori embertani széria tuberkulózis fertőzöttségének vizsgálata morfológiai és molekuláris biológiai módszerekkel. Anthropologiai Közlemények, 53: 35-50.

Pósa, A., Maixner, F., Lovász, G., Molnár, E., Bereczki, Z., Zink, A., Pálfi, Gy. (2013): Revision of tuberculous lesions in the Bácsalmás-Óalmás series - preliminary morphological and biomolecular studies. Anthropologischer Anzeiger, 70(1): 83-100. DOI: 10.1127/0003$5548 / 2012 / 0260$

Pósa, A., Maixner, F., Zink, A.R., Lovász, G., Molnár, E., Bereczki, Zs., Perrin, P., Dutour, O., Sola, C., Pálfi, Gy. (2012): Ancient human tooth samples used for TB paleomicrobial research. Acta Biologica Szegediensis, 56(2): 125-131.

Levelezési cím: Kajdocsi Lovász Gabriella

Mailing address: Szegedi Tudományegyetem, Természettudományi és Informatikai Kar

Embertani Tanszék

Közép fasor 52.

H-6726 Szeged

Hungary

lovaszgabi@gmail.com 
